\title{
Piscine Islet Xenotransplantation
}

\author{
James R. Wright, Jr. \\ University of Calgary Department of Pathology \\ and Laboratory Medicine $\mathcal{E}$ Calgary Laboratory Services \\ Canada
}

\section{Introduction}

In type I diabetes mellitus, the insulin-producing $\beta$-cells have been destroyed by an autoimmune process and, thus, these patients are dependent upon daily insulin injections to sustain life; however, insulin injections are not a cure in that most patients eventually develop long-term complications due to imprecise control of blood glucose levels. Although one or more insulin injections, carefully coordinated with precise dietary and exercise regimens, can improve glycemic control, there is still considerable fluctuation of blood sugar levels throughout the day. Furthermore, excessive insulin administration can cause hypoglycaemia, coma, and brain damage. Insulin administration simply cannot provide the degree of glycemic control provided by the intact pancreatic islet. Normal islets function like thermostats except that they regulate blood glucose levels rather than temperature; islets recognize high or low blood glucose levels and respond by increasing or decreasing insulin secretion on a moment by moment basis, thus providing precise glycemic control throughout the day. There is considerable evidence that precise control of blood glucose levels will prevent the chronic complications of diabetes (Wolffenbuttel, 1993), and this is the primary rationale supporting pancreatic islet transplantation.

Islet allotransplantation could allow for an actual "cure" for type I, and possibly also many patients with type II, diabetes; however, there are several perplexing problems (CITR Research Group, 2009). First of all, although considerable progress has been made with immunosuppressive regimens to promote islet allograft survival, long-term insulin independence occurs in less than $25 \%$ of patients; furthermore, there are potential complications associated with long-term immunosuppression. Therefore, islet allotransplantation is usually limited to type I diabetic patients who have difficulty controlling glycemic levels with insulin therapy and who have frequent hypoglycemic episodes. Second, in human (and mammalian) pancreases, islets comprise only $1-2 \%$ of the pancreas by volume and are scattered throughout. Isolating human islets is not an exact science. Currently, it often requires several human donor pancreases to obtain sufficient islets for a single transplant and the costs associated with each islet isolation procedure are huge. Third, and most importantly, there are simply an inadequate number of suitable human cadaveric donors. There are currently several million type 1 diabetic patients in North America and, each year, there are several tens of thousands of new cases; in stark contrast, there are less than ten thousand suitable donors per year. Thus, the supply of islets is a limiting factor that would likely prevent widespread application of clinical islet allotransplantation. 
Clinical islet xenotransplantation, which could result in a potentially unlimited supply of donor islets, could be an attractive alternative. However, xenotransplantation creates an entirely new set of issues including: (1) selection of an appropriate donor species, (2) xenograft rejection, (3) risk of xenozoonotic disease transmission, (4) animal rights issues, (5) complicated ethical issues pertaining to the rights of recipients, close contacts, and society as a whole, (6) difficult institutional, national, and international regulatory issues, (7) very high potential costs, and (8) whether precious healthcare dollars could be better spent, especially in countries like Canada with public supported healthcare systems (Wright et al., 2004). This chapter will focus primarily on the selection of an appropriate donor but will touch on many of these other issues in passing.

\section{Experimental islet xenotransplantation using tilapia donors}

Unlike mammalians which have very large numbers of very small (microscopic) islets scattered amongst the exocrine pancreas (and comprising only 1-2\% of its total volume), many teleost (i.e., bony) fish have small numbers of very large islets as discrete islet organs called Brockmann bodies. Because these large islets are macroscopically visible and easy to harvest, they actually played an important role in the discovery of insulin and have even been used sporadically over the past 90 years as a source of insulin for clinical treatment of diabetic patients (Wright, 2002a; Wright, 2002b).

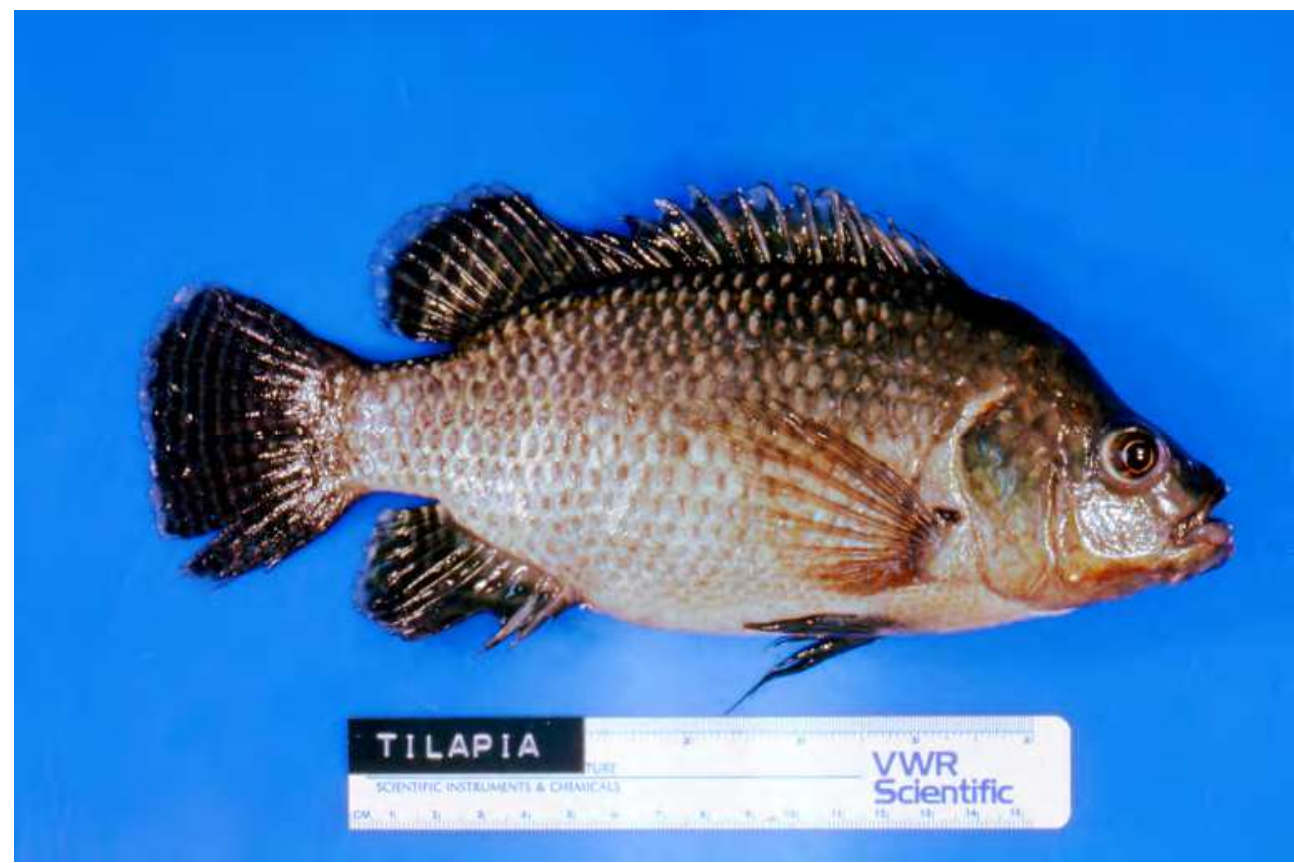

Fig. 1. The Nile Tilapia is a popular food world-wide. It is often produced in large aquaculture systems. A "market size" tilapia weighs about 700-800 grams. The maximum size, in our hands, is about $5 \mathrm{~kg}$ ( 0.5 meter in length). Most of our transplant work is done with tilapia weighing between 500-1,200gm. 
We have used tilapia (Oreochromis niloticus; figure 1), a large, commercially important warm water teleost species, as a source of islets for xenotransplantation research since 1992 (Wright, 1992). We and others have shown that tilapia islets transplanted under the kidney capsules of streptozotocin-diabetic athymic nude mice provide long-term normoglycemia and mammalian-like glucose tolerance profiles (Wright et al., 1992; Morsiani et al., 1995; Leventhal et al, 2004). When transplanted into mice with a normal immune system, tilapia islet grafts are functionally and histologically rejected in 7-8 days (Wright et al., 1994) and graft rejection is characterized by massive infiltration of macrophages, eosinophils, and Tcells (Wright et al., 1997). In general, tilapia islet xenograft rejection is temporally and mechanistically similar to rejection of pig or human islets (Dickson et al., 2003).

\subsection{Harvesting and transplanting tilapia brockmann bodies}

Harvesting tilapia islets is very simple; unlike mammalian islets, there is no need for inflating pancreatic ducts with expensive blends of special collagenases followed by complicated, time-consuming, and fickle islet isolation procedures. As shown in figure 2, Tilapia Brockmann bodies are scattered within the adipose tissue surrounding the common bile duct in a triangular region bounded anteriorly by the edge of the liver, superiorly by the stomach, and inferiorly by the spleen and gall bladder (i.e., "the Brockmann body region").

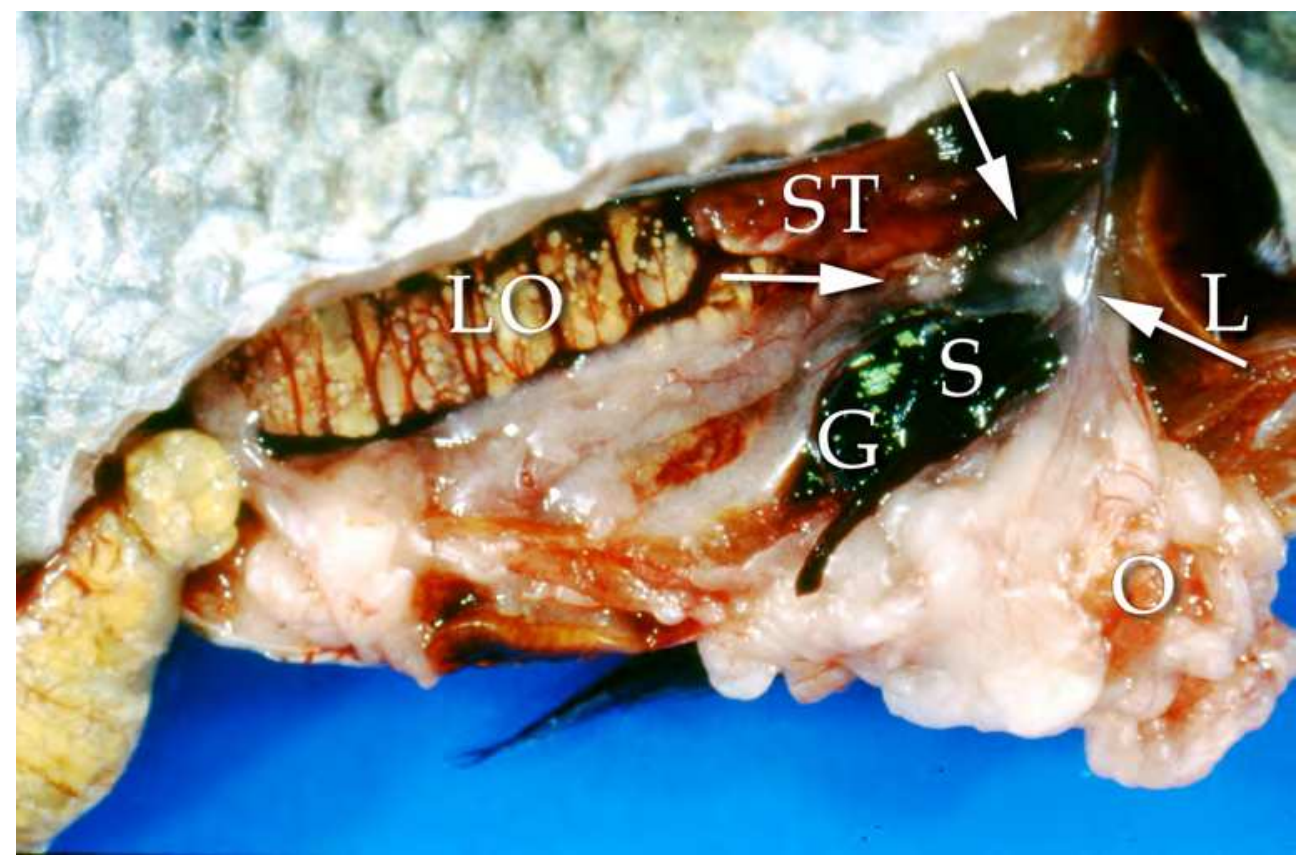

Fig. 2. Dissection of female tilapia with the right ovary and omentum $(\mathrm{O})$ reflected downward reveals the roughly triangular Brockmann body region (outlined by arrows) surrounded by the liver (L), stomach (ST), and spleen (S) and gall bladder (G). LO=left ovary. Reprinted with permission from Yang H, Wright JR Jr. 1995. A method for mass harvesting islets (Brockmann bodies) from teleost fish. Cell Transplantation 4, pp. (621-628). 
The larger islets can be removed simply by excising the entire "region" (figure 3 \& figure 4), placing it in a plastic petri dish with Hank's Balanced Salt Solution, and microdissecting them from the adipose tissue while visualizing them with a dissecting microscope (Wright, 1994). This method works fine but would be inefficient if doing more than a few transplants as it is slow and misses the smaller islets. Alternatively, the islets can be enzymatically massharvested by removing regions from multiple fish simultaneously, placing them in a tube with a type II collagenase (normally used to harvest adipocytes) solution, and then placing the tube in a $37^{\circ} \mathrm{C}$ shaker water bath for 10 minutes; when the incubation period is over, the digestion is stopped by adding cold Hank's, causing the fat cells to float to the top of the tube and islets to remain as a pellet (Yang \& Wright, 1995).

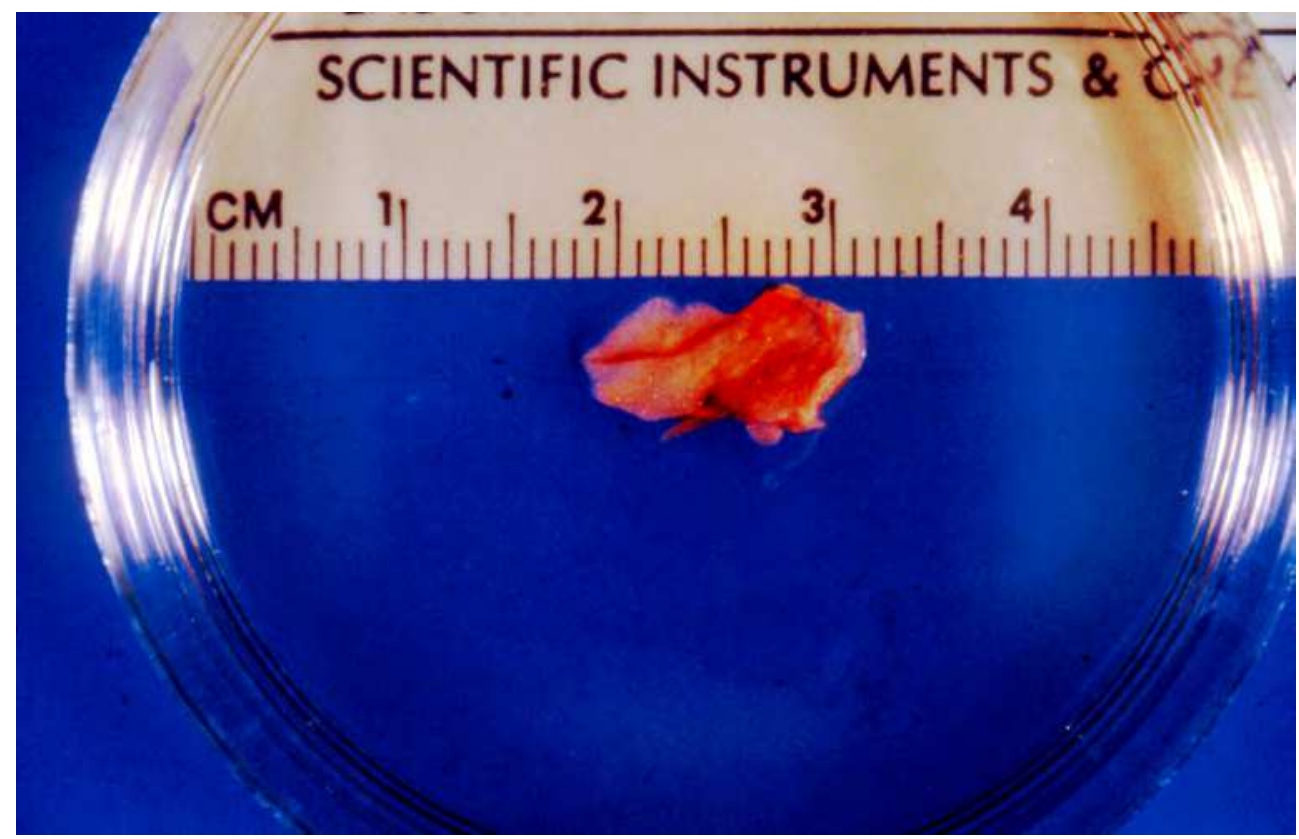

Fig. 3. Excised Brockmann body "region" free floating in Hanks balanced solution salt solution. Reprinted with permission from Yang H, Wright JR Jr. 1995. A method for mass harvesting islets (Brockmann bodies) from teleost fish. Cell Transplantation 4, pp. (621-628).

It should be noted that in large tilapia, some Brockmann bodies can measure up to $5 \mathrm{~mm}$ in maximum dimension [n.b., tilapia produce new islets and their older islets grow throughout their lifespan and so there is a tremendous range in islet size (Morrison et al., 2004)]. For our transplantation work, all large islets are broken up into smaller "mammalian islet" sized fragments (Yang et al., 1997a). After overnight culture, these fragmented islets "round up" and then take on the appearance of mammalian islets. Fragmented islets can then be transplanted immediately, cultured under various conditions (Wright \& Kearns, 1995), or cryopreserved in liquid nitrogen (O'Hali et al., 1997). Fragmentation does not affect the cellular composition or function of the islets because the large islets are comprised of repetitive units similar to smaller islets (Yang et al., 1999a). There is a linear relationship between fish body weight and the number of islet endocrine cells (Dickson et al., 1998); therefore, the sum of the body weights of 
multiple donor fish can be used to predict the total islet cell mass as well as the number of transplants that can be performed (Wright et al., 2004).

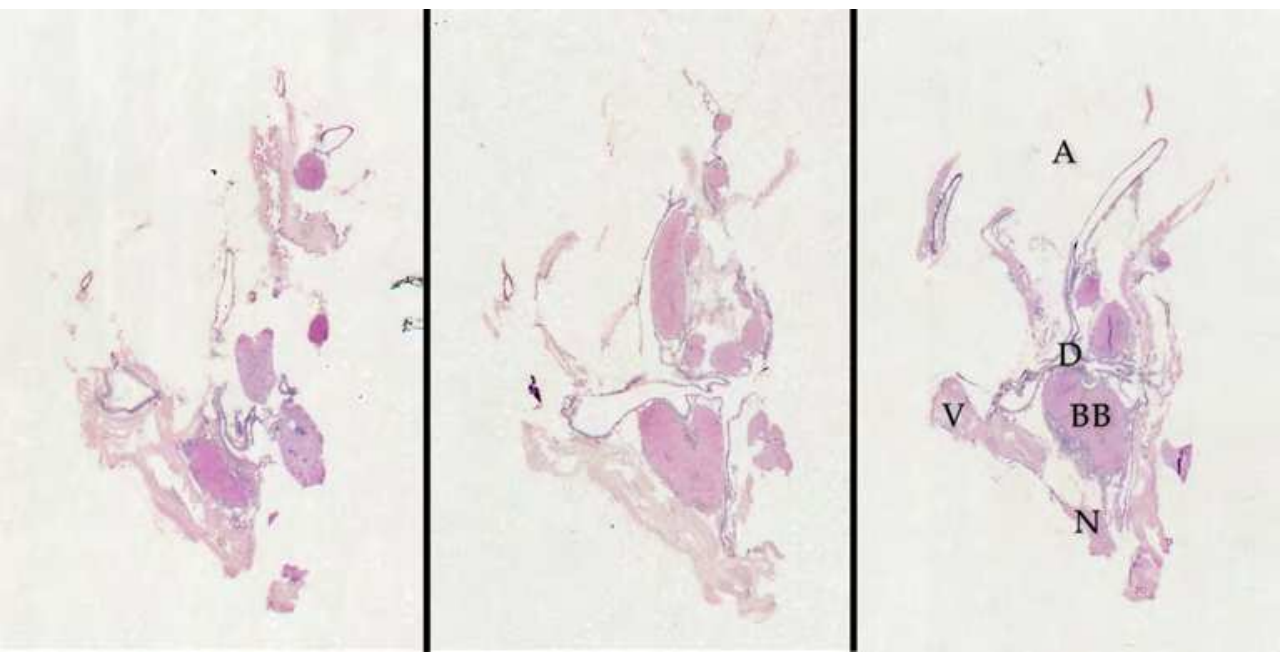

Fig. 4. Whole mount produced by processing an entire Brockmann body region for histology. Sections were cut at three different levels through the block to provide a threedimensional view. Sections were stained with hematoxylin and eosin. The regions are composed of adipose tissue (A), bile and pancreatic ducts (D), blood vessels (V), nerve $(\mathrm{N})$, and Brockmann bodies (BB). Twelve Brockmann bodies can be identified in the center frame. Reprinted with permission from Yang H, Wright JR Jr. 1995. A method for mass harvesting islets (Brockmann bodies) from teleost fish. Cell Transplantation 4, pp. (621$628)$.

In rodents, unencapsulated tilapia islets can be transplanted under the kidney capsule (Yang et al., 1997a), via the portal vein (Al-Jazaeri et al., 2005), or into the non-cryptorchid testes (Coddington et al., 1997). When islets are transplanted into any of these sites, the grafts undergo neovascularisation (i.e., recipient capillaries grow into the grafts). This is one of the features that makes islet transplantation different from whole organ transplantation, in which immediate direct vascular anastomoses are performed. Because Brockmann bodies are discrete and separate from the exocrine pancreas, it is also possible to transplant them as immediately vascularised grafts by microvascular surgical techniques (Yu et al., 2003), creating the unique ability to compare these grafts as either neovascularized cell transplants or directly vascularised organ grafts. This is particularly interesting in the context that tilapia cells are too primitive to express $\alpha(1,3)$ gal, an antigen expressed on mammalian cells (except human and Old World apes), that is responsible for hyperacute rejection of whole organ xenografts in man (Leventhal et al., 2004). Fish islets are also unique in that they can be transplanted into the non-cryptorchid testis; in contrast, mammalian islets only function if transplanted into the cryptorchid testis. The reason for this difference is that the fish are poikilotherms and their islets are fully functional at a wider range of body temperatures whereas mammalian islets require $37^{\circ} \mathrm{C}$. Tilapia islets are very well-suited for encapsulation (see below). 
For experimental studies in which rejection is based upon monitoring function (i.e., ability to lower blood glucose levels), tilapia islets have a major advantage compared to either fetal or neonatal porcine islets, as the latter do not become functional until they have matured after transplantation. Tilapia islets, like adult pig islets, function immediately after transplantation.

\subsection{Xenotransplantation and xenograft rejection}

Initially, we used tilapia islets as an inexpensive tool to screen methods directed at preventing islet xenograft rejection. The vast majority of early studies on islet xenografts were done with the concordant rat-to-mouse model and these studies implied that the islet xenograft rejection process could be easily circumvented (Wright \& Yang, 1997). However, when methods that prevented islet xenograft rejection between concordant species were applied to discordant species combinations, most conferred little real protection. Intuitively, it seemed that it would be hard to imagine any species combination that would be more discordant than fish-to-mammal by virtue of the several hundred million years separating, these orders phylogenetically. The results of studies testing various modalities for their ability to prevent islet xenograft rejection have been reviewed elsewhere but, in general, we found that methods directed at decreasing graft immunogenicity prior to transplantation were ineffective but that chronic high dose immunosuppression was reasonably effective at prolonging islet xenograft survival(Wright \& Yang, 1997; Wright \& Pohajdak, 2001); however, the latter could precipitate post-transplant lymphoproliferative disorder (Yang et al., 2002b). We also developed a heterotopic heart transplant model to prove that xenotransplantation from tilapia to rodent was actually discordant (Yu \& Wright, 1999).

We also used the tilapia-to-mouse model to study the mechanism of xenograft rejection. Generally speaking, the mechanism of rejection of tilapia islets is highly CD4 dependent and appears to be no different than the rejection of pig islets (Dickson et al., 2003). Immune destruction of encapsulated tilapia islets (see below) in spontaneously diabetic NOD mice is also CD4 dependent (Xu et al., 2005).

\subsection{Xenotransplantation with encapsulation}

Encapsulation devices are small semi-permeable chambers in which islets can be placed prior to transplantation and which are designed to protect the islet grafts from the host's immune system (de Vos et al., 2010; Vaithilingam \& Tuch, 2011). These devices are generally divided into macroencapsulation and microencapsulation devices. Both achieve immunoprotection by creating a barrier with "pore" sizes small enough to prevent leukocytes and antibodies from damaging the graft but large enough for oxygen, insulin, glucose and nutrients to pass freely. Encapsulation devices, in general, have a number of associated problems including: (1) none are entirely biocompatible, (2) hypoxia causes graft attrition, (3) device durability issues, (4) pores can shed antigen precipitating inflammation, fibroplasia, and humoral sensitization, (5) cytokines can enter the pores, (6) devices must be replaced or refilled periodically, and (7) devices increase total graft bulk.

Relative to mammalian islets, tilapia islets are highly resistant to hypoxia (Wright et al., 1998b) making them ideal for incorporation into transplantable encapsulation devices (Yang \& Wright, 2002a). We have previously shown that encapsulation markedly prolongs piscine 
islet xenograft survival in small animal recipients (Yang et al., 1997) and that coencapsulation with allogenic or xenogeneic Sertoli cells further prolongs graft survival (Yang \& Wright, 1999). Interestingly, the protective effect of Sertoli cells is not mediated by their Fas-ligand expression as Fas-L deficient Sertoli cells still confer protection (Yang et al., 2002a).

Dionne et al. (1994) have described the "idealized" islet for incorporation into encapsulation devices as follows. "The ideal tissue has a high insulin output, is correctly regulated by glucose and other secretogogues, has low metabolic demand, and is capable of functioning for extended periods without replacement. In addition, the cells must be procurable in high yield at reasonable cost with protocol meeting FDA standards (Dionne et al., 1994). In general, tilapia islets meet these criteria. However, to this definition, we would also add the need for a human insulin-like structure (see below).

\section{Potential clinical islet xenotransplantation using tilapia donors}

Because tilapia islets appear physiologically capable of providing long-term normoglycemia and mammalian-like glucose tolerance profiles, we believe that they could play a future role in clinical islet xenotransplantation. However, there are some significant issues.

First of all, islets are not simply sources of insulin. Islets are comprised of multiple cell types which produce other hormones. In the context of a xenograft, it occurred to us that some of these foreign peptides might either have undesirable biological activity or, even if these other foreign peptides were non-functional, they might serve as antigens and promote antibody reactions as well as immune complex diseases.

Second, little is known about how fish islets maintain normoglycemia. Before one could consider transplanting fish islets into humans, tilapia $\beta$-cell physiology would need to be examined.

Third, although it is known that fish insulins are functional in humans (Wright, 2002a; Wright, 2002b), their amino acid sequences usually differ considerably from that of human insulin and their relative biological activities in man are variable. Tilapia insulin structure differs from human insulin by a total of 17 amino acids (Nguyen et al., 1995), whereas, in contrast, porcine insulin differs at only the $30^{\text {th }}$ amino acid on the B-chain.

Fourth, although it was not known when we began this research, it is now believed that all fish possess two non-allelic insulin genes. Little is known about the Insulin-2 gene in tilapia or other fish.

\subsection{Other islet peptides}

Like mammalian islets, tilapia Brockmann bodies are mostly comprised of insulinproducing $\beta$-cells, glucagon-producing a-cells, and somatostatin (SST)-producing $\delta$-cells. However, there are some fundamental differences. First of all, the fourth primary peptide in mammalian islets is Pancreatic Polypeptide while in tilapia it is Peptide-YY; both typically represent $1-2 \%$ of the islet cells and will not be further discussed here. Second, fish islets have two different types of $\delta$-cells, one producing the 14 amino acid SST-1 (n.b., the sequence of this peptide is identical in all vertebrates) and the other a "large" SST, the 
product of the preproSST-II gene (either not present or not expressed in mammals). Third, the percentages of the different cell types in mammals and tilapia differ greatly. In mammals, the insulin-producing $\beta$-cells predominate $(\sim 70 \%)$, glucagon-producing $\alpha$-cells represent $\sim 20 \%$, and SST-producing $\delta$-cells comprise $<10 \%$; in tilapia, the percentage of $\beta$, $a$, $\delta-1$, and $\delta-2$ cells are $42.3 \%, 11.5 \%, 21.8 \%$, and 23.1\% (Yang et al., 1999a). Fourth, the glucagon-producing a-cells in fish simultaneous produce glucagon-like peptide (GLP)-1; mammals, in contrast, produce two different GLPs, GLP-1 and GLP-2, and GLP-1 is produced in the intestinal L-cells, while fish make only GLP-1, and it is produced only in the islet $\alpha$-cells. Fifth, in mammals, most islets are composed of a central $\beta$-cell core and the non$\beta$-cells are at the periphery of the islet; in contrast each tilapia Brockmann body, which is much larger than mammalian islet, is comprised of many repetitive units containing a central core of $\beta$-cells encased by a thin layer of SST- $1 \delta$-cells which are surrounded by SST-2 $\delta$-cells and scattered $\alpha$-cells (Yang et al., 1999a). Because of this highly repetitive nature, Brockmann bodies fragmented for transplantation contain all cell types.

These differences create several interesting scenarios related to xenotransplantation. First of all, in the context of the two different SSTs, SST-1 is 100\% homologous with all mammalian SSTs, and, thus, should be biologically active while the second large SST would be biologically irrelevant and likely antigenic and could potentially precipitate immune complex disease. However, after xenotransplantation into streptozotocin-diabetic nude mice, the cells producing this peptide, the $\delta$-2-cells, decreased from roughly $25 \%$ of the cells in the islet graft to negligible numbers in less than 2 months, apparently due to apoptosis secondary to the lack of any piscine trophic stimulation after xenotransplantation into a mammalian environment (Morrison et al., 2003b). Equally interesting was the observation that the percentage of the various endocrine cell types in the grafts became increasingly mammalian-like as time passed (Morrison et al., 2003b). One further observation was that co-expression of GLP-1 and glucagon persisted throughout the study. This is intriguing as GLP-1 is known to promote improved glucose homeostasis and $\beta$-cell neogenesis, which could be an advantageous by-product of fish islet xenotransplantation.

\subsection{Glucose homeostasis and $\beta$-cell function in tilapia}

Until recently, little was known about glucose homeostasis in fish. This is probably not surprising as there are very few fish species in which glucose is a significant component of their natural diets. In fact, it was generally believed that fish islets were not particularly glucose responsive (Wright et al., 2000). However, a simple xenotransplantation study using tilapia islets disproved this. In this study, glucose tolerance tests were performed in intact fish and it took them roughly 3 days to dispose of glucose loads, thus demonstrating extreme glucose intolerance (as had been shown previously in other fish species); however, when the tilapia islets were harvested from donor fish and engrafted under the kidney capsule of streptozotocin-diabetic nude mice, these same islets disposed of an equivalent glucose load in less than 30 minutes, suggesting that insulin secretion by tilapia islets was highly glucose-responsive but that the reason tilapia (and presumably other fish) were glucose intolerant was because of an extreme peripheral resistance to the glucostatic effects of insulin (Wright et al., 1998a). More recently, we have confirmed the glucose responsiveness of tilapia islets in vitro and have dissected the regulation of insulin gene expression and insulin production in tilapia islets (Hrytsenko et al., 2008). Interestingly, we also found insulin gene expression in the tilapia brain and pituitary (Hrytsenko et al., 2007). 
Like in mammalian islets, the "glucose sensor" in the tilapia $\beta$-cell is glucokinase (Joy, 2002). However, the glucose sensor must partner with a glucose transporter and we are less certain as to the primary glucose transporter in the tilapia $\beta$-cell (Alexander et al., 2006; Hrytsenko et al., 2010). In rodent islets, GLUT-2 is the primary glucose transporter but in human islets it is GLUT-1. We have demonstrated high levels of expression of both transporters in tilapia Brockmann bodies; however, circumstantial evidence leads us to favor GLUT-1. Streptozotocin and alloxan are highly toxic to rodent $\beta$-cells and induce severe diabetes; both are known to enter the $\beta$-cell via GLUT-2 rather than GLUT-1; human $\beta$-cells, which preferentially utilize GLUT-1, are highly resistant to both drugs. Tilapia $\beta$-cells, like human $\beta$-cells, are resistant to the diabetogenic effects of streptozotocin and alloxan (Wright et al., 1999; Yang \& Wright, 2002b; Xu et al., 2004).

Alexander et al. (2006) have reviewed many other aspects of tilapia islet physiology. The readers are referred to this review for a more detailed analysis.

\subsection{Tilapia insulin structure and transgenic tilapia expressing a humanized insulin gene}

Although tilapia islets provide many advantages relative to mammalian islets, the tilapia insulin structure differs from human insulin structure by 17 amino acids and we felt that this would likely preclude their clinical use. Therefore, we decided to make and patent transgenic tilapia expressing a "humanized" tilapia insulin gene (Wright \& Pohajdak, 2000; Wright \& Pohajdak, 2002). This was accomplished by cloning and sequencing the tilapia insulin gene (Mansour et al. 1998), modifying it by site directed mutagenesis changing only the codons representing the 17 amino acids that differed between human and tilapia insulin, and then microinjecting the "humanized" tilapia insulin transgene via the micropile into fertilized tilapia eggs (Pohajdak et al., 2004). Resulting offspring were simultaneously screened by PCR using tilapia insulin gene-specific primers and humanized tilapia insulin gene-specific primers. One founder, who was later shown to be a mosaic (Wright et al., 2008), demonstrated germ-line expression and passed the transgene on to some of his offspring. Positive offspring were segregated and grown to a size large enough to safely bleed and collect plasma for human insulin measurements. Some offspring with high levels of circulating human insulin were sacrificed for histology; figure 5 shows the presence of human insulin-positive $\beta$-cells in a transgenic Brockmann body and absence of human insulin staining in $\beta$-cells from a wild-type tilapia Brockmann body. Figure 6 shows that islet architecture (i.e., distribution of other endocrine cell types) is unchanged in transgenic tilapia islets.

It should be noted, in order to maintain appropriate cleavage by the endopeptidases, the terminal amino acid on the B-chain was omitted and, therefore, our trangenics secrete [desThrB30] human insulin. In comparison, porcine insulin differs from human insulin by substitution of an Ala for the terminal Thr; whereas our transgenic human insulin is simply missing the terminal Thr.

Eventually, while battling government regulatory and other nightmares (Wright, 2006; Wright et al., 2012), we were able to breed these transgenic fish to homozygosity and have now demonstrated lifelong transgene expression (Hrytsenko et al., 2010; Hrytsenko et al., 2011). We hope to begin early pre-clinical transplantation studies soon. 

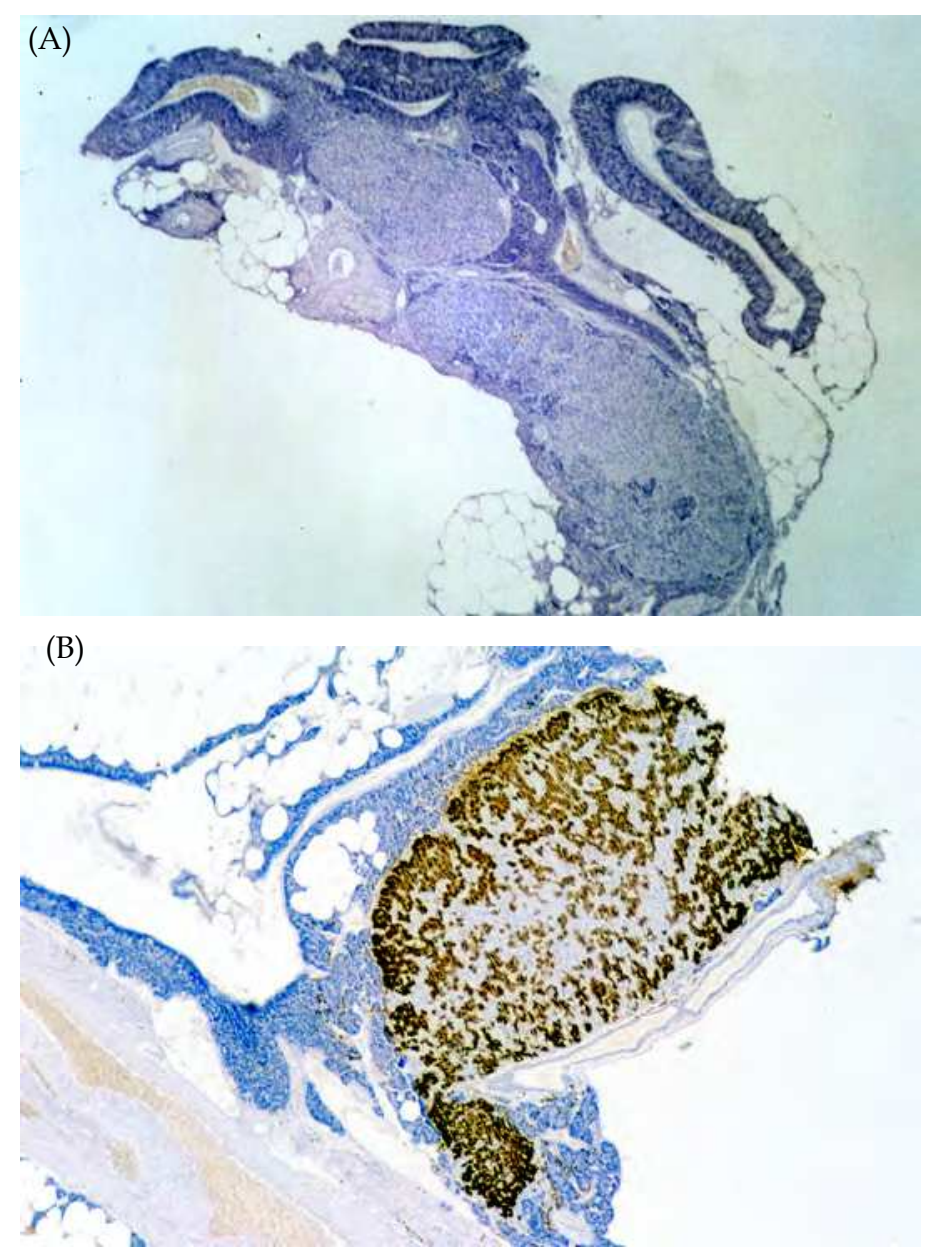

Fig. 5. Histologic sections of pancreatic islets from control (A) and transgenic (B) juvenile tilapia. Sections are stained for human insulin by immunoperoxidase. Note the clusters of immunopositive $\beta$-cells in the transgenic islets and the absence of staining in the control islets. Consistent results were obtained using several different commercially available monoclonal and polyclonal antibodies for human insulin. Reprinted with permission from Pohajdak B, Mansour M, Hrytsenko O, Conlon JM, Dymond C, \& Wright JR Jr. 2004. Production of transgenic tilapia with Brockmann bodies secreting [desThrB30] human insulin. Transgenic Res. 13, 4, pp. (313-323).

Eventually, we believe that we will need to either knockout the native tilapia insulin gene or at least silence it. Methods for producing gene knockout fish are still in their infancy with almost all of the work in this field having been performed in zebrafish or Japanese medaka. In general, the process, like in mice, will likely involve creating ES cells from tilapia blastulas at the $\sim 1000$ cell stage, knocking out the native tilapia insulin gene in vitro through homologous recombination, and then microinjecting these ES-cells back into developing 
tilapia blastulas, screening for cutaneous chimerism, screening these chimeras for germ-line chimerism, and then breeding to homozygosity. Little of the work done in zebrafish and medaka is directly applicable and so we have done some of the preliminary work characterizing early embryogenesis in tilapia to facilitate these studies (Morrison et al., 2001; Morrison et al. 2003a) and have demonstrated the ability to make chimeras by microinjecting blastula cells (Wright et al., 2012).

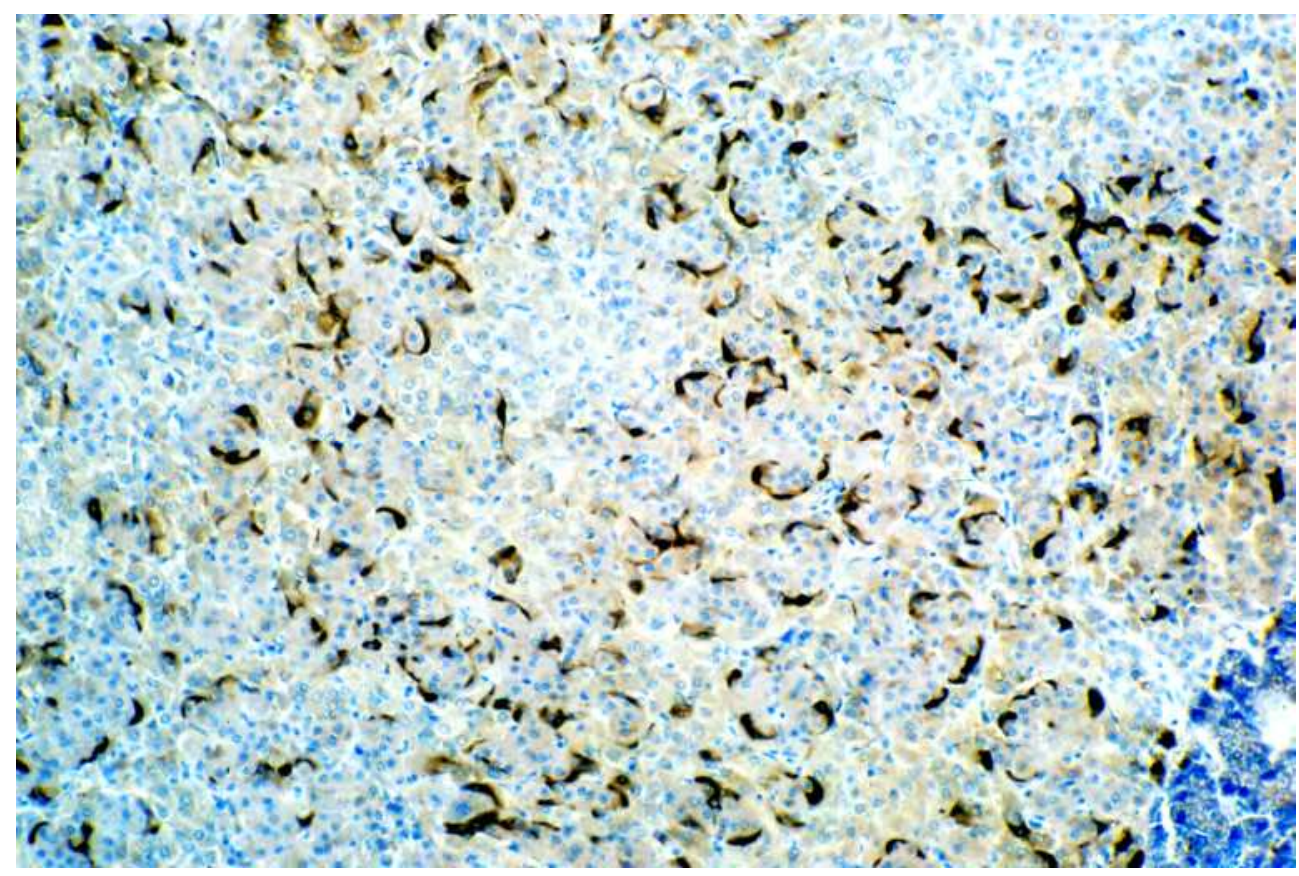

Fig. 6. Histologic sections of pancreatic islets from transgenic tilapia stained for human SST1 by immunoperoxidase. Note the concave shape of individual and small groups of SST-1+ $\delta$-cells. These cells directly encase clusters of $\beta$-cells and are surrounded by SST-2+ $\delta$-cells (staining not shown here). The overall architecture of the Brockmann body is unchanged in transgenics.

\subsection{Two non-allelic insulin genes}

Recently, from studying genomic maps of zebrafish, medaka, and fugu (pufferfish), it has become apparent that ancestral fish underwent a genomic duplication several hundred million years ago and that these modern-day fish possess a second non-allelic insulin gene (Taylor et al., 2003). This may not be surprising as genome duplication appears to have played a major role in evolution as the "big leaps" cannot be explained by natural selection acting on necessary genes; big leaps required new gene loci with redundant function that could accumulate forbidden mutations (Conlon \& Larhammar, 2005). Furthermore, such an insulin gene duplication would not be unique as it has long been known that rat and mouse islets express two non-allelic insulin genes (Lomedico et al., 1980) and there is even some evidence that the porcine insulin gene may be duplicated (Snel \& Damgaard, 1980). 
However, it critical to know whether tilapia have two non-allelic insulin genes and, if so, whether the second insulin gene is expressed and a product secreted as the transgenic tilapia that we produced by microinjecting a "humanized" tilapia insulin gene possess islets that simultaneously secrete both human insulin and tilapia insulin. Therefore, our plan is to knock out or silence the native tilapia insulin gene in these transgenics, resulting in donors with islets that secrete only human insulin. However, unless it has been deleted during evolution, it seemed highly probable that tilapia possess a second insulin gene and that, if it is expressed, this might adversely affect our ability to produce a donor strain with islets secreting only human insulin.

Therefore, degenerative primers were designed based upon the alignment of the available sequences for fish insulin 2 genes and we cloned most of the NTins2 (nile tilapia insulin 2) gene and studied tissue-specific expression. Analysis of the primary protein organization revealed that the precursor molecule consists of the four typical preproinsulin regions: signal peptide, B chain, C chain, and A chain; prohormone convertase processing sites were determined and the peptide appeared to be potentially biologically active (Hrytsenko, 2007).

Using qRT-PCR, we examined the levels of Insulin 2 gene expression in islets and other tissues and compared this with Insulin 1 gene and actin expression. Insulin 2 gene expression occurred in all tested tissues, except for adipose tissue, at exceedingly low levels, and the level of expression in tilapia islets was not significantly higher than in other tissues. This almost uniform pattern of insulin 2 expression resembles the expression pattern for house keeping genes, and is in contrast to the more tightly restricted $\beta$-cell-specific transcription of the insulin 1 gene. It is most likely that the NTins2 gene is transcribed at low levels in essentially all extrapancreatic tissues and its transcription is only slightly upregulated in the pancreatic islets. Moreover, translation of the second insulin may actually be suppressed by the presence of a short reading frame upstream of the insulin initiation codon (Hrytsenko, 2007). Regardless, it seems unlikely that the insulin 2 product will need to be silenced in transgenic tilapia islets.

\section{Conclusions}

As documented above, tilapia islets have played a significant role in experimental islet xenotransplantation research. Advantages include ease of harvesting, total cost of procured islets, and the ability to transplant them into multiple body sites and have them function immediately after transplantation (not true for either fetal or neonatal pig islets); on the other hand, the major disadvantage is the need for specialized animal housing facilities, as aquatic facilities are not available at all research institutions. Transgenic tilapia islets expressing a humanized insulin gene may also play a role in future clinical islet xenotransplantation. We now have homozygous transgenics ready for pre-clinical testing.

We conservatively estimate, based upon animal husbandry and islet isolation costs, that production costs for transgenic tilapia islets should be at least 100-fold less expensive than porcine islets on a per clinical transplant basis (Wright et al., 2004). This advantage could greatly facilitate the widespread implementation of clinical islet xenotransplantation as a cure for type I diabetes. 


\section{Acknowledgment}

Financial support has been provided by the Juvenile Diabetes Research Foundation, the University of Calgary Faculty of Medicine, and Calgary Laboratory Services.

\section{References}

Alexander E, Dooley KC, Pohajdak B, \& Wright JR Jr. (2006). Things we've learned from tilapia islet xenotransplantation. Gen. Com. Endocrinol. 148, 2, pp. (125-131)

Al-Jazaeri A, Xu B-Y, Yang H, MacNeil D, Leventhal JR, \& Wright JR Jr. (2005). Effect of glucose toxicity on intraportal tilapia islet xenotransplantation in nude mice. Xenotransplantation 12, pp. (189-196)

Coddington DA, Lawen JG, Yang H, O'Hali W, \& Wright JR Jr. (1997). Xenotransplantation of fish islets into the non-cryptorchid testis. Transplant. Proc. 29, pp. (2083-2085)

Conlon JM \& Larhammar D. (2005). The evolution of neuroendocrine peptides. Gen. Comp. Endocrinol. 142, pp. (53-59)

CITR Research Group. (2009). 2007 update on allogeneic islet transplantation from the Collaborative Islet Transplant Registry (CITR). Cell Transplant. 18, 7, pp. (753-767)

de Vos P, Spasojevic M, \& Faas MM. (2010). Treatment of diabetes with encapsulated islets. Adv Exp Med Biol. 670, pp. (38-53)

Dickson B, Yang H, Pohajdak B, \& Wright JR Jr. (1998). Quantification of tilapia islets: a direct relationship between islet cell number and body mass. Transplant. Proc. 30, pp. (621-622)

Dickson BC, Yang H, Savelkoul HFJ, Rowden G, van Rooijen N, \& Wright JR Jr. (2003). Islet transplantation in the discordant tilapia-to-mouse model: a novel application of alginate microencapsulation in the study of xenograft rejection. Transplantation 75 , pp. (599-606)

Dionne K, Scharp D, Lysaght M Hegre P, \& Lacy P. (1994). Macroencapsulation of islets for the treatment of diabetes. In: Lanza PR, Chick WL, eds. Pancreatic Islet Transplantation. Vol. 3. Immunoisolation of the Pancreatic Islets, RG Landes Co., pp. (119-131), Austin

Hrytsenko O. (2007). Molecular characterization of the insulin genes in Nile tilapia (Oreochromis niloticus). PhD Dissertation, Dalhousie University, Halifax, Nova Scotia, Canada

Hrytsenko O, Pohajdak B, \& Wright JR Jr. (2010). Production of transgenic tilapia homozygous for a humanized insulin gene. Transgenic Res. 19, 2, pp. (305-306)

Hrytsenko O, Pohajdak B, Xu B-Y, Morrison CM, van Tol B, \& Wright JR Jr. (2010). Cloning and molecular characterization of the Glucose Transporter 1 in tilapia (Oreochromis niloticus). Gen. Comp. Endocrinol. 165, 2, pp. (293-303)

Hrytsenko O, Rayat G, Xu B-Y, Pohajdak B, Krause R, Rajotte RV, \& Wright JR Jr. (2011). Lifelong stable human insulin expression in transgenic tilapia expressing a humanized tilapia insulin gene. Transgenic Res. - in press

Hrytsenko O, Wright JR Jr, Morrison CM, \& Pohajdak B. (2007). Insulin expression in the brain and pituitary cells of tilapia (Oreochromis niloticus). Brain Res. 1135, 1, pp. (31-40)

Hrytsenko O, Wright JR Jr, \& Pohajdak B. (2008). Regulation of insulin gene expression and insulin production in Nile tilapia (Oreochromis niloticus). Gen. Comp. Endocrinol. 155,2 , pp. $(328-340)$ 
Joy P. (2001). Cloning, sequencing, and expression of the tilapia glucokinase. MSc Thesis, Dalhousie University, Halifax, Nova Scotia, Canada

Leventhal JR, Sun JD, Zhang J, Galili U, Chong A, Baker M, Kaufman D, \& Wright JR Jr. (2004). Evidence that tilapia islets do not express $a(1,3) \mathrm{Gal}$ : Implications for islet xenotransplantation. Xenotransplantation 11, pp. (276-283)

Lomedico PT, Rosenthal N, Kolodner R, Efstratiadis A, \& Gilbert W. (1980). The structure of rat preproinsulin genes. Ann. N.Y. Acad. Sci. 343, pp. (425-432)

Mansour M, Wright JR Jr, \& Pohajdak B. (1998). Cloning, sequencing and characterization of the tilapia insulin gene. Comp. Biochem. Physiol. 121B, pp. (291-297)

Morrison CM, Miyake T, \& Wright JR Jr. (2001). Development of embryo and early larva of Oreochromis niloticus (Pisces: Cichlidae). J. Morphol. 247, pp. (172-195)

Morrison CM, Pohajdak B, Tam J, \& Wright JR Jr. (2004). Development of the islets, exocrine pancreas and related ducts in the Nile tilapia, Oreochromis niloticus (Pisces: Cichlidae). J. Morphol. 261, pp. (377-389)

Morrison CM, Pohajdak B, \& Wright JR Jr. (2003a). Structure and enzymatic removal of the chorion of embryos of the Nile tilapia Oreochromis niloticus. J. Fish Biol. 63, pp (14391453)

Morrison CM, Yang H, Al-Jazaeri A, Tam J, Plisetskaya E, \& Wright JR Jr. (2003b). Xenogeneic milieu markedly remodels endocrine cell populations after transplantation of fish islets into streptozotocin-diabetic nude mice. Xenotransplantation 10, pp. (60-65)

Morsiani E, Lebow LT, Rozga J, \& Demetriou AA. (1995). Teleost fish islets: a potential source of endocrine tissue for the treatment of diabetes. J. Surg. Res. 58, pp. (583591)

Nguyen T, Wright JR Jr, Nielsen PF, \& Conlon JM. (1995). Characterization of the pancreatic hormones from the Brockmann body of the tilapia - implications to islet xenograft studies. Comp. Biochem. Physiol. 111C, pp. (33-44)

O'Hali W, Yang H, Pohajdak B, LaPrairie A, Gross M, \& Wright JR Jr. (1997). Cryopreservation of fish islets: the effect on function and islet xenograft survival. Transplant. Proc. 29, pp. (1990-1991)

Pohajdak B, Mansour M, Hrytsenko O, Conlon JM, Dymond C, \& Wright JR Jr. (2004). Production of transgenic tilapia with Brockmann bodies secreting [desThrB30] human insulin. Transgenic Res. 13, 4, pp. (313-323)

Snel L \& Damgaard U. (1988). Proinsulin heterogeneity in pigs. Horm. Metab. Res. 20, pp. (476-480)

Taylor JS, Braasch I, Frickey T, Meyer A, \& Van de Peer Y. (2003). Genome duplication, a trait shared by 22000 species of ray-finned fish. Genome Res. 13, pp. (382-390)

Vaithilingam V \& Tuch BE. (2011). Islet transplantation and encapsulation: an update on recent developments. Rev Diabet Stud. 8, 1, pp. (51-67)

Wolffenbuttel BH. (1993). The DCCT: "Metabolic control matters." Diabetes Control and Complications Trial. Neth J Med. 43, 5-6, pp. (241-245)

Wright JR Jr. (1992). Experimental transplantation using principal islets of teleost fish (Brockmann bodies). In: Pancreatic Islet Cell Transplantation: 1892-1992 - One Century of Transplantation for Diabetes, C Ricordi, RG Landes Co., pp. (336-351), Austin 
Wright JR Jr. (1994). Procurement of fish islets (Brockmann bodies). In: Pancreatic Islet Transplantation Series. Volume 1: Procurement of Pancreatic Islets, RP Lanza and WL Chick, RG Landes Co., pp. (125-135), Austin

Wright JR Jr. (2002a). From ugly fish to conquer death: JJR Macleod's fish insulin research, 1922-24. The Lancet 359, pp. (1238-1242)

Wright JR Jr. (2002b). Almost famous: E. Clark Noble, the common thread in the discovery of insulin and vinblastine. CMAJ 167, pp. (1391-1396)

Wright JR Jr. (2006). Academic uses of GM fish technology: A call for a common sense approach to regulation. In: Assessment of Environmental and Indirect Human Health Effects of Genetically Modified Aquatic Organisms, RH Devlin, Canadian Technical Report of Fisheries and Aquatic Sciences 2581, Department of Fisheries \& Oceans Canada, pp. (111-126), Ottawa

Wright JR Jr, Abraham C, Dickson BC, Yang H, \& Morrison C. (1999). Streptozotocin dose response curve in tilapia, a glucose-responsive teleost fish. Gen. Comp. Endocrinol. 114, pp. (431-440)

Wright JR Jr, Bonen A, Conlon JM, \& Pohajdak B. (2000). Glucose homeostasis in the teleost fish tilapia: insights from Brockmann body xenotransplantation studies. American Zoologist 40, pp. (234-245)

Wright JR Jr, Hrytsenko O, \& Pohajdak B. (2012). Transgenic tilapia for islet xenotransplantation. In: Aquaculture Biotechnology, G. Fletcher and M. Rise, Blackwell Publications - in press

Wright JR Jr \& Kearns H. (1995). Long-term culture, low temperature culture, and hyperoxic culture do not prolong fish-to-mouse islet xenograft survival. Xenotransplantation 2, pp. (19-25)

Wright JR Jr, Kearns H, Polvi S, MacLean H, \& Yang H. (1994). Experimental xenotransplantation using principal islets of teleost fish (Brockmann bodies): Graft survival in selected strains of inbred mice. Transplant. Proc. 26, pp. (770)

Wright JR Jr, Kearns H, Yang H, Fraser RB, Colp P, \& Rowden G. (1997). Immunophenotyping fish-to-mouse islet xenograft rejection: A time course study. Ann. Transplant. 2, 3, pp. (12-16)

Wright JR Jr, O'Hali W, Yang H, \& Bonen A. (1998a). GLUT-4 deficiency and absolute peripheral resistance to insulin in the teleost fish tilapia. Gen. Comp. Endocrinol.111, pp. (20-27)

Wright JR Jr \& Pohajdak B. (issued 1/18/2000). Transgenic fish and a method of harvesting islet cells therefrom. US Patent No. 6,015,713

Wright JR Jr \& Pohajdak B. (2001). Cell therapy for diabetes using piscine islet tissue. Cell Transplant.10, pp. (125-143)

Wright JR Jr \& Pohajdak B. (issued 11/5/2002). Transgenic tilapia comprising a humanized insulin gene. U.S. Patent No. 6,476,290 B1

Wright JR Jr, Pohajdak B, Xu B-Y, \& Leventhal JR. (2004). Piscine islet xenotransplantation. ILAR J. 45, pp. (314-323)

Wright JR Jr, Polvi S, \& MacLean H. (1992). Experimental transplantation with principal islets of teleost fish (Brockmann bodies): Long-term function of tilapia islet tissue in diabetic nude mice. Diabetes 41, pp. (1528-1532)

Wright JR Jr, Snowden J, Hrytsenko O, Morrison CM, \& Pohajdak B. (2008). Immunohistochemical staining for tilapia and human insulin demonstrates that a 
tilapia transgenic for humanized insulin is a mosaic. Transgenic Res. 17, 5, pp. (991992)

Wright JR Jr \& Yang H. (1997). Tilapia Brockmann bodies: An inexpensive, simple model for discordant islet xenotransplantation. Ann. Transplant. 2, 3, pp. (72-76)

Wright JR Jr, Yang H, \& Dooley KC. (1998b). Tilapia -A source of hypoxia-resistant islets for encapsulation. Cell Transplant. 7, pp. (299-307)

Xu B-Y, Morrison CM, Yang H, \& Wright JR Jr. (2004). Tilapia islets grafts are highly alloxan-resistant. Gen. Comp. Endocrinol. 137, pp. (132-140)

Xu B-Y, Yang H, Serreze DV, MacIntosh R, Yu W, \& Wright JR Jr. (2005). Rapid destruction of encapsulated islet xenografts by NOD mice is CD4 dependent and facilitated by B-cells: Innate immunity and autoimmunity do not play significant roles. Transplantation 80, pp. (402-409)

Yang H, Al-Jazaeri A, \& Wright JR Jr. (2002a). The immunoprotective effect of Sertoli cells co-encapsulated with islet xenografts is not dependent upon Fas-ligand expression. Cell Transplant. 11, pp. (799-801)

Yang H, Dickson B, O'Hali W, Kearns H, \& Wright JR Jr. (1997a). Functional comparison of mouse, rat, and fish islet grafts transplanted into diabetic nude mice. Gen. Comp. Endocrinol. 106, pp. (384-388)

Yang H, McAlister VC, al-Jazaeri A, \& Wright JR Jr. (2002b). Liposomal encapsulation significantly enhances the immunosuppressive effect of tacrolimus in a discordant islet xenotransplant model. Transplantation 73, pp. 710-713

Yang H, Morrison CM, Conlon JM, Laybolt K, \& Wright JR Jr. (1999a). Immunocytochemical characterization of the pancreatic islet cells of the tilapia (Oreochromis niloticus). Gen. Comp. Endocrinol. 114, pp. (47-56)

Yang H, O'Hali W, Kearns H, \& Wright JR Jr. (1997). Long-term function of fish islet xenografts in mice by alginate encapsulation. Transplantation 64, pp. (28-32)

Yang H \& Wright JR Jr. (1995). A method for mass harvesting islets (Brockmann bodies) from teleost fish. Cell Transplant. 4, pp. (621-p628)

Yang H \& Wright JR Jr. (1999). Co-encapsulation of Sertoli enriched testicular cell fractions further prolongs fish-to-mouse islet xenograft survival. Transplantation. 67, pp. (815820)

Yang H \& Wright JR Jr. (2002). Microencapsulation methods: Alginate $\left(\mathrm{Ca}^{+2}\right.$-induced gelation). In: Methods of Tissue Engineering A Atala and R Lanza, Academic Press, pp. (787-801), New York

Yang H \& Wright JR Jr. (2002b). Human beta cells are exceedingly resistant to streptozotocin in vivo. Endocrinology 143, pp. (2491-2495)

Yu W, Xu B-Y, \& Wright JR Jr. (10/03/03). Directly vascularized pancreatic islet xenotransplantation: Is tilapia-to-nude mouse discordant? $7^{\text {th }}$ International Xenotransplantation Congress, Glasgow, UK

Yu W \& Wright JR Jr. (1999). Heterotopic cardiac xenotransplantation: fish-to-rat. Xenotransplantation 6, pp. (213-219) 


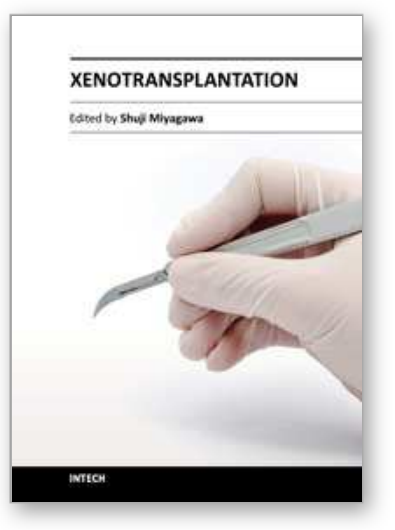

\author{
Xenotransplantation \\ Edited by Prof. Shuji Miyagawa
}

ISBN 978-953-307-997-4

Hard cover, 126 pages

Publisher InTech

Published online 03, February, 2012

Published in print edition February, 2012

Accompanied by the advent of animal cloning, the technique of nuclear transfer produced alpha1,3galactosyltransferase-knockout (Gal-KO) pigs in many institutes, including the ones in Japan, at the beginning of 21 st Century. In addition, the controversy of the risks of PERV has gradually minimized, because of the fact that there are no cases of PERV infections reported in humans. Furthermore, a large clinical wave for islet allotransplantation resumed the interest of xenotransplantation, especially porcine islet transplantation and some exceptions. Clinical trials were done in many countries so far, such as Sweden, China, Mexico, USA (Inventory of Human Xenotransplantation Practices - IXA and HUG in collaboration with WHO). In addition, a new clinical trial was approved by the government, and resumed the porcine islet transplantation research in New Zealand two years ago.

\title{
How to reference
}

In order to correctly reference this scholarly work, feel free to copy and paste the following:

James R. Wright, Jr. (2012). Piscine Islet Xenotransplantation, Xenotransplantation, Prof. Shuji Miyagawa (Ed.), ISBN: 978-953-307-997-4, InTech, Available from: http://www.intechopen.com/books/xenotransplantation/piscine-islet-xenotransplantation

\section{INTECH}

open science | open minds

\section{InTech Europe}

University Campus STeP Ri

Slavka Krautzeka 83/A

51000 Rijeka, Croatia

Phone: +385 (51) 770447

Fax: +385 (51) 686166

www.intechopen.com

\section{InTech China}

Unit 405, Office Block, Hotel Equatorial Shanghai

No.65, Yan An Road (West), Shanghai, 200040, China

中国上海市延安西路65号上海国际贵都大饭店办公楼405单元

Phone: $+86-21-62489820$

Fax: +86-21-62489821 
(C) 2012 The Author(s). Licensee IntechOpen. This is an open access article distributed under the terms of the Creative Commons Attribution 3.0 License, which permits unrestricted use, distribution, and reproduction in any medium, provided the original work is properly cited. 